Review

\title{
New Treatment Addressing the Pathogenesis of Psoriasis
}

\author{
Michio Tokuyama * and Tomotaka Mabuchi \\ Department of Dermatology, Tokai University School of Medicine, 143 Shimokasuya, Isehara, \\ Kanagawa 259-1193, Japan; mabuchi@is.icc.u-tokai.ac.jp \\ * Correspondence: tokuyama@tokai-u.jp
}

Received: 19 August 2020; Accepted: 8 October 2020; Published: 11 October 2020

check for updates

\begin{abstract}
Psoriasis is an immune cell-mediated inflammatory skin disease. The interleukin (IL)23/IL17 axis plays an important role in the development of psoriasis. The effectiveness of biologic treatments such as tumor necrosis factor (TNF) $\alpha$ inhibitors (infliximab, adalimumab, certolizumab pegol), IL23 inhibitors (ustekinumab, guselkumab, tildrakizumab, risankizumab), and IL17 inhibitors (secukinumab, ixekizumab, brodalumab) have verified these findings. Immune-related cells such as dendritic cells (DCs) and macrophages, in addition to Toll-like receptors and cytokines such as interferon (IFN) $\alpha, \mathrm{TNF} \alpha$, IFN $\gamma$, IL12, IL22, IL23, and IL17, are related to the pathogenesis of psoriasis. Here, we first review new insights regarding the pathogenesis of psoriasis, as it relates to DCs, Langerhans cells, macrophages, the signal transducer and activator of transcription 3 pathway, and aryl hydrocarbon receptor in cutaneous vascular endothelial cells. Based on these findings, we summarize currently available oral treatments and biologics. Furthermore, we describe a new treatment option including Janus kinase inhibitor, tyrosine kinase 2 inhibitor, modulator of sphingosine 1-phosphate receptor 1, and Rho-associated kinase 2 inhibitor.
\end{abstract}

Keywords: psoriasis; new treatment; pathogenesis; dendritic cells; Janus kinase inhibitor; sphingosine 1-phosphate receptor 1; Rho-associated kinase 2 inhibitor; aryl hydrocarbon receptor

\section{Introduction}

Psoriasis is a chronic inflammatory cutaneous disease characterized by the formation of scaly, indurated, erythematous plaques. Psoriasis has three principal histologic features: epidermal hyperplasia; dilated, prominent blood vessels in the dermis; and an inflammatory infiltrate of leucocytes, predominantly into the dermis [1]. Not only limited to the skin, psoriasis also affects joints and nails. Psoriasis is mainly divided into three clinical types: psoriasis vulgaris, psoriatic arthritis, and generalized pustular psoriasis (GPP). Psoriasis often coexists with other systemic disorders including obesity, hypertension, hyperlipidemia, diabetes, metabolic syndrome, cardiovascular disease, which is called psoriatic march or inflammatory march, and chronic kidney disease [2,3]. Psychiatric disorders, psychosocial distress such as depression are also seen in psoriatic patients [4].

These comorbidities and symptoms affect the choice of treatments. The pathogenesis of psoriasis involves antimicrobial peptides (AMPs), dendritic cells (DCs), tumor necrosis factor (TNF) $\alpha$, interleukin (IL)23, Th17, IL17, IL22, and signal transducer and activator of transcription (STAT)3 (Figure 1, Table 1). In this review, we focus on the development of psoriasis and summarize new treatments based on new insights (Figure 2, Table 2). 


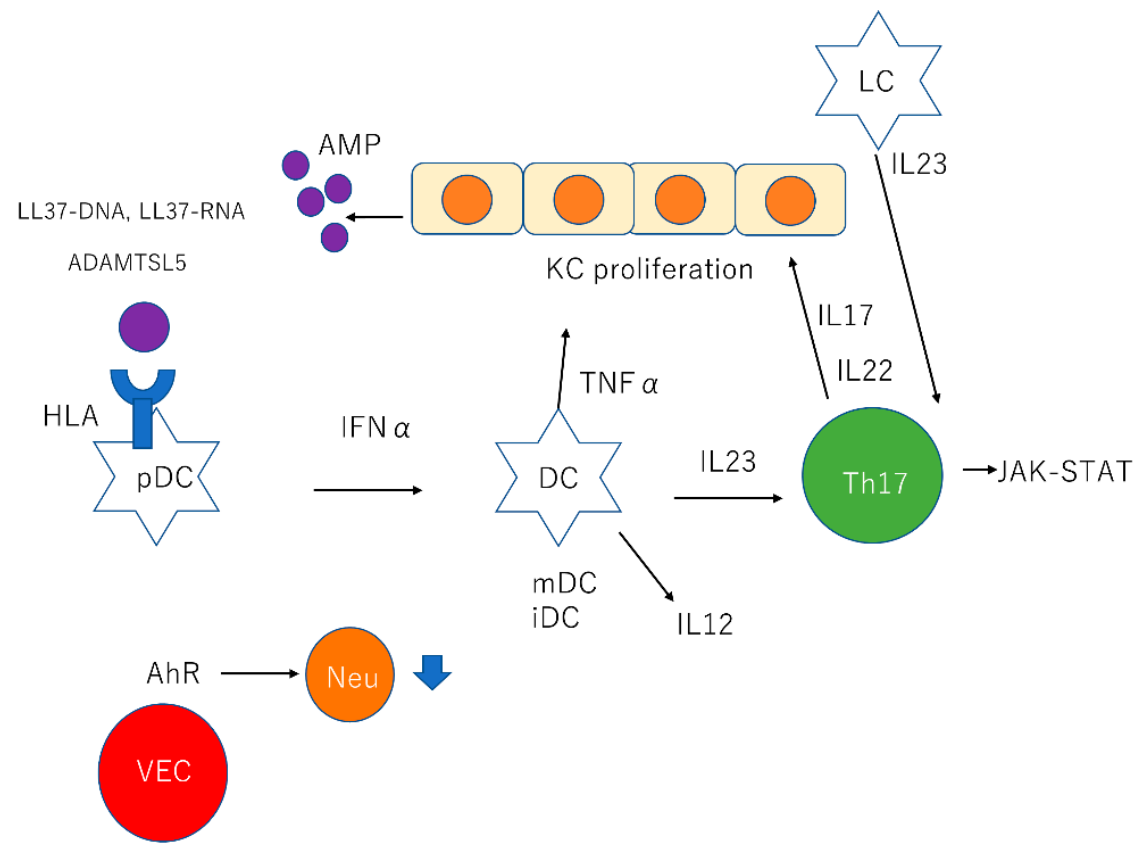

Figure 1. Summary of pathogenesis of psoriasis. KCs produce AMPs such as $\beta$-defensins, S100 proteins, and cathelicidin. LL37 and ADAMTSL5 are considered to be as autoantigens. LL37-DNA complexes stimulate $\mathrm{pDCs}$, and $\mathrm{pDC}$ secrete IFN $\alpha$. LL37-RNA complexes stimulate mDCs and mDCs produce TNF $\alpha$, IL23, and IL12. IL23 stimulates Th17 cells and Th17 cells produce IL17 and IL22 through the JAK-STAT pathway. LCs also secrete IL23 and stimulate Th17 cell. AhR in cutaneous VECs downregulate neutrophil recruitment. KC: keratinocyte; AMP: antimicrobial peptides; ADAMTSL5: A disintegrin and metalloprotease domain containing thrombospondin type 1 motif-like; pDC: plasmacytoid dendritic cell; IFN: interferon; mDC: myeloid dendritic cell; iDC: inflammatory dendritic cell; TNF: tumor necrosis factor; IL: interleukin; JAK: Janus kinase; STAT: signal transducer and activator of transcription; LC, Langerhans cell; AhR: aryl hydrocarbon receptor; VEC: vascular endothelial cell; Neu: neutrophil; HLA: human leukocyte antigen.

Table 1. Summary of pathogenesis of psoriasis.

\begin{tabular}{cc}
\hline Cell Type & Description \\
\hline KCs & KCs produce AMPs such as $\beta$-defensins, S100 proteins, and cathelicidin \\
pDCs & pDCs stimulated by LL37-DNA complexes produce IFN $\alpha$ \\
mDCs & mDCs stimulated by LL37-RNA complexes produce TNF $\alpha$, IL23, and IL12. \\
LCs & LCs produce IL23 \\
Th17 cells & Th17 cells stimulated by IL23 produce IL17 and IL22 through JAK-STAT \\
pathway & IL17 recruits neutrophil and proliferates KCs \\
VECs & AhR in cutaneous VECs downregulate neutrophil recruitment
\end{tabular}

KC: keratinocyte; AMP: antimicrobial peptides; pDC: plasmacytoid dendritic cell; IFN: interferon; mDC: myeloid dendritic cell; iDC: inflammatory dendritic cell; TNF: tumor necrosis factor; IL: interleukin; JAK: Janus kinase; STAT: signal transducer and activator of transcription; LC, Langerhans cell; AhR: aryl hydrocarbon receptor; VEC: vascular endothelial cell; Neu: neutrophil; HLA: human leukocyte antigen. 
a)

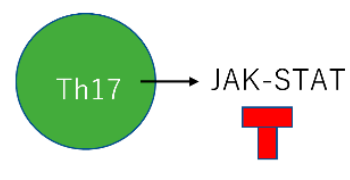

JAK inhibitor c)

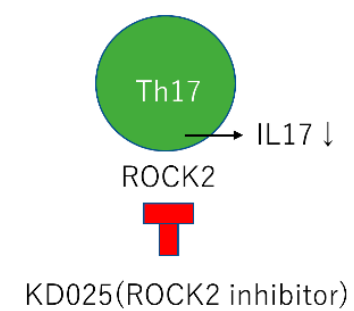

d)

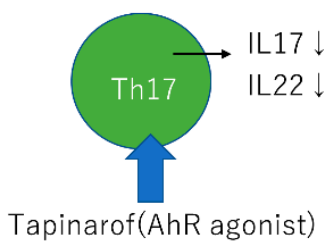

Figure 2. Summary of new treatment. (a) JAK inhibitor blocks the JAK-STAT signal pathway in Th17 cells. (b) Ponesimod, a selective S1P1 agonist, induces sequestration of lymphocytes into lymph nodes and decreases peripheral lymphocyte counts and trafficking of lymphocytes to peripheral tissues. (c) KD025, ROCK2 inhibitor reduces IL17 secretion in Th17 cells. (d) Tapinarof, AhR agonist reduces IL17 and IL22 in Th17 cells. JAK: Janus kinase; STAT: signal transducer and activator of transcription; S1PR1: sphingosine-1-phosphate receptor 1; ROCK2: Rho-associated kinase 2; IL: interleukin; AhR: aryl hydrocarbon receptor.

Table 2. Summary of new treatments under clinical trials for psoriasis.

\begin{tabular}{cccc}
\hline Name & Target & Stage & Dosage Form \\
\hline VTP-43742 & ROR $\gamma$ t inhibitor & Phase 2 & Oral \\
GSK2981278 & ROR $\gamma$ inverse agonist & Phase 1 & Topical \\
BI 655130 & IL36-receptor antagonist & Phase 1 & Intravenous \\
Tofacitinib & JAK inhibitor & Phase 3 & Oral \\
Baricitinib & JAK1/JAK2 inhibitor & Phase 2 & Oral \\
BMS-986165 & TYK2 inhibitor & Phase 2 & Oral \\
PF-06700841 & TYK2/JAK1 inhibitor & Phase 2 & Topical \\
Ponesimod & S1PR1 agonist & Phase 2 & Oral \\
KD025 & ROCK2 inhibitor & Phase 2 & Oral \\
Tapinarof & AhR agonist & Phase 2 & Topical \\
\hline
\end{tabular}

\section{Pathogenesis of Psoriasis}

\section{1. $A M P S$}

AMPs are composed of 12-50 amino acids, have positive charge, amphipathic structure, and play important roles in host protection by killing pathogenic microorganisms including bacteria, protozoa, fungi, and viruses [5,6]. AMPs also affect host inflammatory responses by acting as chemotactic agents, angiogenic factors, and regulators of cell proliferation in vertebrates [6]. In psoriasis, certain AMPs, including $\beta$-defensins, S100 proteins, and cathelicidin, are highly expressed and secreted by keratinocytes, neutrophils, and macrophages in response to injury and cytokine stimulation (Figure 1) [7].

The defensins are cationic microbicidal peptides separated into three categories; defensins $\alpha, \beta$, and $\theta$ [8]. The $\alpha$-defensins are further separated into six subtypes designated as human neutrophil peptides (HNPs) 1-6, and HNPs 1-3 are present in the scales of psoriatic lesions [9]. The $\beta$-defensins 
are separated into four subtypes designated as human $\beta$-defensins (hBDs) $1-4$. TNF $\alpha$ and IFNrinduce hBDs 2 and 3, which are highly present in the psoriatic scales, and IL17A and IL22 also induce hBDs 2 in keratinocytes [6]. The role of defensins in the pathogenesis of psoriasis is not yet fully understood [10].

The S100 proteins comprise a family of low-molecular-weight (9-13 kDa) proteins [11]. S100A7 (psoriasin), S100A8 (calgranulin A), S100A9 (calgranulin B), S100A12 (calgranulin C), and S100A15 are highly expressed in psoriasis [8]. The combination of IL22, IL17A, IL17F, and keratinocytes synergistically induced the expression of $\beta$-defensin 2, S100A9, S100A7, and S100A8 [12]. S100A7 (psoriasin) is reported as a potent and selective chemotactic inflammatory protein for $\mathrm{T}$ cells and neutrophils in psoriasis [13].

Cathelicidin LL37 is the C-terminal peptide fragment derived from hCAP18 [14]. Plasmacytoid DCs (pDCs) recognize self-DNA through TLR9 and LL37 is the key factor that mediates pDCs' activation in psoriasis [15]. Furthermore, keratinocytes exposed to LL37 and self-DNA produce type I IFN, which is related to the development of psoriasis (Figure 1) [16].

LL37 bound to RNA stimulates pDCs through TLR7 and LL37-RNA complexes act on myeloid DCs (mDCs) through TLR8 $[7,10,16]$. Activated mDCs migrate into draining lymph nodes and produce TNF $\alpha$, IL23, and IL12. Slan+ monocytes also respond to LL37-RNA activation and produce TNF $\alpha$, IL23, and IL12 (Figure 1) [17]. IL23 and IL12 induce naïve T cell to Th17 and Th1 cell subsets, respectively [7].

An in silico docking study by Mabuchi et al. confirmed that multiple 9-mer peptides derived from LL37 exhibit high binding affinities for $H L A-C^{*} 06: 02$ molecules, and they proposed a mechanism for the interaction between LL37 HLA-C*06:02 complexes and T cells via T-cell receptors [18].

\subsection{A Disintegrin and Metalloprotease Domain Containing Thrombospondin Type 1 Motif-Like 5 (ADAMTSL5)}

The melanocyte-derived protein ADAMTSL5 has been identified as an autoantigen [19]. Intra-epidermal CD8 T cells recognize ADAMTSL5 on melanocytes in association with HLA-C*06:02 [19]. Keratinocytes produce ADAMTSL5 with IL17 stimulation and CXCL1, which is a neutrophil chemoattractant and melanocyte growth factor, induce ADAMTSL5 expression [19]. In psoriasis, the number of melanocytes is increased and $\mathrm{T}$ cells including cytotoxic $\mathrm{T}$ cells co-localize with these melanocytes [20]. However, it is suggested that melanocytes are likely targets of the non-cytotoxic CD8+ $\mathrm{T}$ cell-mediated autoimmune response because the number of melanocytes increase, but melanocytes do not show signs of cell death in psoriasis [21]. The ADAMTSL5 expression pattern mirrors the pattern of $\mathrm{T}$ cell infiltration and DC aggregation in the superficial dermis in psoriasis, which is similar to LL37 [22]. The expression of ADAMTSL5 and LL37 with DCs, neutrophils, macrophages, and T cells in psoriasis significantly decreases after treatment of IL17 or TNF $\alpha$ blocker $[23,24]$. This suggests that ADAMTSL5 and LL37 are presented to autoreactive CD4+ T cells by HLA-class II molecules and to $\mathrm{CD} 8+\mathrm{T}$ cells by HLA-Cw6 $6^{*} 02$, which are expressed on the surface of antigen-presenting cells within the dermal lymphoid tissue structures $[19,24]$. A synthetic ADAMTSL5 peptide increases the frequency of CD8 T cells expressing IL17A and IFNramong the peripheral blood mononuclear cells in psoriasis patients, but the same effect is not found in healthy individuals [19].

\section{3. $D C s$}

The skin contains a complex network of DCs mainly composed of epidermal Langerhans cells (LCs), bone-marrow-derived dermal conventional DCs (cDCs), pDCs, and inflammatory DCs (iDCs) [25]. As the prominent cellular source of IFN $\alpha, \operatorname{TNF} \alpha$, IL12, and IL23, DCs play an important role in psoriasis [25].

pDCs originate in the bone marrow and migrate to the skin under pathologic conditions [25]. pDCs recognize viral nucleic acids and produce large amounts of type I IFNs in response to endosomal Toll-like receptors (TLRs), such as TLR7 and 9 [26-29]. Inappropriate recognition of self-nucleic acids by $\mathrm{pDC}$ results in producing IFN $\alpha$ and initiating psoriatic inflammation $[29,30]$. The AMPs such as LL37, human $\beta$-defensin (hBD) 2, hBD3, and lysozyme are able to condense self-DNA or RNA into 
particles that are endocytosed by pDCs, leading to activation of TLR7, 8, and 9 in psoriasis [29-31]. In psoriatic inflammation, IFN $\alpha$ is considered to act as an upstream cytokine along the IL23/IL17 axis [32]. IFN $\alpha$ strongly activates immature cDCs to secrete IL12, IL15, IL18, and IL23 [33]. In addition, IFN $\alpha$ induces the rapid differentiation of human monocytes into iDCs and polarizes CD4+ T cells into Th1 and Th17 cells [34,35]. Furthermore, IFN $\alpha$ also enhances the reaction to IL22 on epidermal keratinocytes by upregulating IL22 receptor expression [36].

Under healthy conditions, cDCs are also associated with maintaining immune tolerance through depletion of autoimmune $\mathrm{T}$ cells, expressing anti-inflammatory cytokines and inhibitory receptors including IL10, transforming growth factor (TGF) $\beta$, and IL27 and prompting the homeostasis of regulatory T cells (Tregs) [37,38]. Dysregulation of this tolerance mechanism has been found in many autoimmune diseases such as psoriasis $[39,40]$. By inducing tolerogenic DCs, $\alpha$-melanocyte-stimulating hormone ameliorates psoriasis by promoting Treg expansion and downregulating the proliferation of human and murine Th17 cells and cytokine production [41]. cDCs are activated by multiple cytokines such as IL6, TNF $\alpha$, IFN $\alpha$, and also LL37-RNA complexes [25]. Activated cDCs produce a mass of inflammatory cytokines such as IL12 and IL23, which are key mediators in psoriasis [25].

iDCs are considered to be derived from monocytes and have the ability to polarize T cells to Th1, Th2, and Th17 and produce cytokines such as IL1, IL6, TNF $\alpha$, IL12, IL22, and IL23 [27]. In psoriasis, $\mathrm{TNF} \alpha$, and inducible nitric oxide synthase (iNOS)-producing DCs (Tip-DCs) and 6-sulfo LacNAc DCs (slanDCs) are reported as iDCs, and they induce T cells to secrete IL17, IL22, TNF $\alpha$, and IFN $\gamma$ [14]. SlanDCs are also stimulated by TNF $\alpha$ and produce IL12, IL23, IL1 $\beta$, and IL6 [17].

The number of LCs in psoriasis is likely to be variable, as it can increase [42], decrease [43], or remain the same [44]. Subsequent experiments demonstrated that increased expression of IL17 is responsible for impaired LC migration in the uninvolved skin of patients with psoriasis [45]. Recent studies demonstrated that activation of the STAT3 pathway in keratinocytes and TLRs in LCs can induce LCs to produce IL23 and monocyte-derived LCs (mLCs) exhibit a more powerful ability to secrete IL23 when compared with resident LCs (rLCs) (Figure 1) [44,46]. Furthermore, LCs are in close contact with $\mathrm{T}$ cells in patients who achieved almost complete remission after anti-TNF $\alpha$ treatment, and they retain a higher capacity for secreting IL23 when compared with healthy volunteers following TLR7/8 stimulation in vitro [25]. This emphasizes that LCs may be associated with recurrence of psoriasis, although this ability is to a small extent comparable with progressive stage psoriasis [44]. Recent studies have shown that LCs indeed produce IL23, and the close proximity to pathogenic T cells suggests that LCs may as be associated with the pathogenesis of psoriasis as other DCs [25]. However, a negative regulatory role of LCs has been observed. The function of LCs in psoriasis varies, and LCs may function as the gate that regulates the degree of inflammatory responses in the disease [25].

\subsection{IL23/IL17 Axis}

IL17 is produced by Th17, Tc17, innate lymphoid cells, and $\gamma \delta \mathrm{T}$ cells in the skin $[47,48]$. IL23 expressed by dermal DCs drives IL17 production [49]. IL17 is produced, as well as TNF, IL26, and IL29 (IFN $\lambda 1$ ), under specific situations such as psoriasis autoantigens and/or certain environmental stimuli (e.g., trauma or infection) [50]. These cytokine signals create a feed forward inflammatory response in keratinocytes by activating CCAAT enhancer-binding protein (C/EBP) $\beta$ or $\delta$, STAT1, and nuclear factor $\mathrm{kB}$ [49]. This feed-forward response accelerates the development of psoriasis [49]. IL17 collaborates with TNF to potentiate IL17-induced transcription of several proinflammatory genes (e.g., TNF, IL1 $\beta$, IL6, and IL8) [51]. They activate mDCs and promote the differentiation of Th17 cells in the skin and draining lymph nodes [52].

IL17 regulates epidermal hyperplasia indirectly by activating STAT3 and promotes keratinocytes to induce IL19, IL36 [50]. IL22, which is mainly produced by Th17 and possibly IL20, also activates STAT3 and induces epidermal hyperplasia (Figure 1) [53]. In the upper spinous and granular layers of the epidermis of psoriatic lesions, IL17-induced transcription factors (e.g., C/EBP $\beta$ or C/EBP $\delta$ ) and keratinocyte-derived gene products, including S100A7/8/9, hBD2, lipocalin-2, and CCL20 are 
increased [49,54]. IL17 in psoriasis has the ability to recruit neutrophils and macrophages by inducing keratinocytes to produce CXCL1, CXCL2, CXCL3, CXCL5, and CXCL8 (i.e., IL8) [46]. IL17A, IL22, and TNF also stimulate CCL20 expression in keratinocytes [55]. CCL20 attracts CCR6+ cells such as $\mathrm{mDC}$ and Th17 cells and sustains the inflammatory response through a positive chemotactic feedback loop [55]. Keratinocytes in psoriasis produce platelet-derived growth factor, angiopoietin-2, and vascular endothelial growth factor, and these growth factors result in erythematous skin lesions [56].

\subsection{Aryl Hydrocarbon Receptor (AhR)}

The AhR is a cytosolic ligand-activated receptor and transcription factor, which is widely expressed in the skin cells $[57,58]$. Endogenous and exogenous molecules and dioxins are known as ligands of AhR $[57,58]$. AhR activation induces oxidative stress through CYP1A1 and neutralizes oxidative stress through the nuclear factor-erythroid 2-related factor-2 (NRF2) transcription factor [59]. Furthermore, AhR regulates the balance of the Th17/22 system, which is important for developing psoriasis [59]. AhR agonists decreased IL-23 receptor, Th17 master transcription factor retinoic acid-related orphan receptor C (RORC) and the number of Th17 cells [60].

In addition, AhR in cutaneous vascular endothelial cells (VECs) also plays an important role in the development of psoriasis [61]. Zhu et al. found that AhR in cutaneous VECs downregulates neutrophil recruitment through adhesion molecule ICAM-1 in psoriasis using specific AhR knockout mice (Figure 1) [61].

\section{Treatment}

\subsection{Currently Available Oral Systemic Therapy}

\subsubsection{Retinoids}

Retinoids are derivatives of vitamin A and bind to nuclear receptors, retinoic acid receptors, and retinoid X receptors, which regulate gene transcription such as IL6 [6]. Retinoids induce keratinocyte differentiation and reduce epidermal hyperplasia, leading to a slowing of cell reproduction [62]. Etretinate, which is a second-generation retinoid, is used in Japan, and acitretin, which is an active metabolite of etretinate, has a shorter half-life, and is eliminated more rapidly than etretinate, is used in many countries [62]. The Psoriasis Area Severity Index 75 (PASI75) response to acitretin 25, 35, and $50 \mathrm{mg}$ /day groups at week 12 were $47 \%, 69 \%$, and 53\%, respectively [63]. The main adverse effects were dry mouth, cheilitis, pruritus, teratogenicity, and elevations in serum lipid and liver enzymes [62,63].

\subsubsection{Methotrexate}

Methotrexate (MTX) inhibits dihydrofolate reductase (DHFR), an enzyme that participates in the tetrahydrofolate synthesis. MTX induces inhibition of purine, methionine, and thymidylate synthesis and inhibits DNA synthesis [64]. Low-dose MTX may have anti-inflammatory effects, including increased adenosine levels, and modulates immune cells [64]. The PASI75 response to MTX at week 12 was $45.2 \%$ [65]. The main adverse events were nausea, vomiting, mouth ulcers, upper respiratory infection, abnormal liver function tests, and interstitial lung disease [65].

\subsubsection{Cyclosporine A}

Cyclosporine A (CyA) is a calcineurin inhibitor. CyA forms a complex with cyclophilin and blocks phosphatase activity of calcineurin and decreases the production of inflammatory cytokines including in T cells [6,66]. The PASI75 response to CyA $5 \mathrm{mg} / \mathrm{kg}$ and $2.5 \mathrm{mg} / \mathrm{kg}$ at week 10 to 16 was $50-97 \%$ and $28-85 \%$, respectively [66]. The main adverse effects are nephrotoxicity, hepatotoxicity, hypertension, an increased risk of infection, and lymphoma [66]. 


\subsubsection{Apremilast}

Apremilast is a selective inhibitor of the enzyme phosphodiesterase 4 (PDE4), which breaks down cyclic adenosine monophosphate (cAMP). PDE4 is the main enzyme in immune cells such as T cells, macrophages, and epithelial cells [6]. Through PDE4 inhibitors, the level of cAMP increases and cAMP downregulates proinflammatory cytokine including TNF $\alpha$ and upregulates anti-inflammatory cytokine including IL10. The PASI75 response to apremilast at week 12 was 33.1\% [67]. The main adverse events are diarrhea, vomiting, and depression [67].

\subsection{Currently Available Biologic Therapy}

\subsubsection{TNF $\alpha$ Inhibitors}

Infliximab, adalimumab, and certolizumab pegol are currently available for the treatment of psoriasis as TNF $\alpha$ inhibitors. Certolizumab pegol is an Fc-free, PEGylated TNF $\alpha$ inhibitor. It does not bind the neonatal $\mathrm{Fc}$ receptor for $\mathrm{IgG}(\mathrm{FcRn})$ and consequently shows minimal placental transfer from mothers to infants [68]. At week 10, PASI 75 response rates for infliximab at $5 \mathrm{mg} / \mathrm{kg}$ dose were $80 \%$ [69]. At week 16, PASI 75 response rates for adalimumab at $40 \mathrm{mg}$ after an initial $80 \mathrm{mg}$ dose were $80 \%$ [70]. At week 16, PASI 75 response rates for certolizumab pegol at $400 \mathrm{mg}$ were $80.1 \%$ [71]. The main severe adverse events were reactivation of hepatitis B and C, tuberculosis, drug-induced lupus, demyelinating central nervous system disorders, and paradoxical reactions such as psoriasis and psoriasiform skin lesions $[69,70]$.

\subsubsection{IL23 Inhibitors}

Ustekinumab, guselkumab, risankizumab, and tildrakizumab are currently available for the treatment of psoriasis as IL23 inhibitors. At week 12, PASI 75 response rates for ustekinumab at $45 \mathrm{mg}$ and $90 \mathrm{mg}$ were $67.5 \%$ and $73.8 \%$, respectively [72]. At week 16, PASI 75/90/100 response rates for guselkumab at $100 \mathrm{mg}$ were $91.2 \% / 73.3 \% / 37.4 \%$ and for risankizumab at $150 \mathrm{mg}$ were $90.8 \% / 74.8 \% / 50.7 \%$ [73,74]. At week 28, PASI 75/90/100 response rates for tildrakizumab at $100 \mathrm{mg}$ were $77 \% / 54 \% / 23 \%$ [75]. The main adverse effects were nasopharyngitis, upper respiratory tract infection, headache, and tiredness [72-75].

\subsubsection{IL17 Inhibitors}

Secukinumab, ixekizumab, and brodalumab are currently available for the treatment of psoriasis as IL17 inhibitors. At week 12, PASI75/90/100 response rates for secukinumab at $300 \mathrm{mg}$ were $77.1 \% / 54 \% / 24 \%$, for ixekizumab at $80 \mathrm{mg}$ after an initial $160 \mathrm{mg}$ were $90 \% / 70 \% / 40 \%$, and for brodalumab at $210 \mathrm{mg}$ were $83 \% / 70 \% / 42 \%$, respectively [76-78]. The main adverse events were candidiasis, neutropenia, inflammatory bowel disease, and depression and risk of suicide in brodalumab [76-78].

\section{3. $R O R \gamma$ t Inhibitors}

Retinoic acid receptor-related orphan nuclear receptor gamma $t$ (ROR $\gamma t$ or RORc2) is a key transcription factor for Th17 cell differentiation [4]. Inhibiting ROR $\gamma \mathrm{t}$ activity is thought to be a promising strategy for the treatment of psoriasis [4]. A phase 2a clinical trial of ROR $\gamma \mathrm{t}$ inhibitor VTP-43742 in psoriatic patients was conducted [79]. A significant reduction in the psoriasis area severity index (PASI) score relative to the placebo was observed in the $350 \mathrm{mg}(24 \%)$ and $700 \mathrm{mg}(30 \%)$ dose groups [79]. However, reversible transaminase elevations were observed in the $700 \mathrm{mg}$ dose group in four patients. Because of this liver toxicity, the initially planned third clinical trial of VTP-43742 was discontinued [79]. Although the phase 1 clinical trial of GSK2981278 ointment (selective ROR $\gamma$ inverse agonist) showed a lack of efficacy, new topical ROR $\gamma \mathrm{t}$ inhibitors may be a potential candidate for the treatment of psoriasis $[80,81]$. 


\subsection{IL36 Receptor Antagonist}

IL36 is an IL1 superfamily member and plays an important role for recruiting and activating neutrophils and Th17 cells in psoriasis [82]. Loss-of-function mutations have been found in IL36RN, which encodes an IL36-receptor antagonist, in some GPP patients [83]. In the phase 1 clinical trial, an intravenous single dose of BI 655130, a monoclonal antibody against the interleukin-36 receptor showed good efficacy regardless of the presence of the IL36RN mutation over a 20-week period [83].

\subsection{Janus Kinase (JAK) Inhibitors}

Type 1 and 2 cytokine receptors strongly depend on the JAK and STAT pathways [84]. The JAK family is intracellular protein tyrosine kinase and includes JAK1,2,3, and TYK2, and the STAT family includes STAT1, 2, 3, 4, 5a, 5b, and 6 [84]. The functions of each JAK and STAT are different [84]. The IL23 receptor, which is important in psoriasis, is associated with JAK2, TYK2, and STAT3 [84]. JAK inhibitors are currently being tested in clinical trials for the treatment of psoriasis (Table 2) [85].

Tofacitinib, which is a first-generation JAK inhibitor, primarily targets JAK3, JAK2, and JAK1 [85]. In the phase 3 studies, the PASI75 response to tofacitinib at weeks $16-24$ was $39.5-54.3 \%$ ( $5 \mathrm{mg}$ twice daily) and $59.2-81.1 \%$ (10 mg twice daily), as compared to 5.6-12.5\% for the placebo [86-89]. During the study, increased circulating total cholesterol, low-density lipoprotein cholesterol, high-density lipoprotein cholesterol, and creatinine phosphokinase levels and decreased blood hemoglobin and lymphocyte counts were observed [85]. Serious adverse events including angina pectoris, pyelonephritis, urosepsis, and atrial fibrillation were observed in three patients [90]. Nasopharyngitis, sinusitis, upper respiratory tract infection, back pain, and headache were observed as adverse events [90]. Now, new JAK inhibitors such as JAK1/JAK2 inhibitor baricitinib are under clinical trial and exhibited good results [91].

The TYK2 inhibitor BMS-986165, which is a more selective JAK inhibitor than first-generation candidates, showed efficacies of $75 \%$ (12 mg daily), when compared to $7 \%$ in the placebo group in terms of PASI75 response at week 12 of treatment in a phase 2 clinical trial [85].

The TYK2/JAK1 inhibitor PF-06700841 directly suppresses TYK2-dependent IL12 and IL23 signaling, and JAK1-dependent signaling in cells such as T cells and keratinocytes [92]. PF-06700841 improves clinical symptoms of chronic plaque psoriasis by inhibiting proinflammatory cytokines that require TYK2 and JAK1 for signal transduction [92]. Topical PF-06700841 is now under investigation in a phase 2 trial [93].

\subsection{Sphingosine-1-Phosphate (S1P) Agonist}

Sphingosine is created from ceramide, which is composed of membrane lipids, through ceramidase [94]. S1P is created from sphingosine through sphingosine kinase [94]. S1P is a lipid mediator and associated with cellular proliferation, survival, migration, inflammation, immune cell trafficking, angiogenesis, vascular integrity, and adhesion in the immune and vascular systems [95]. S1P acts on five specific G protein-coupled receptors named S1P receptor (S1PR)1-5 [95].

S1PR1 is expressed on lymphocytes and controls their egress from thymus and secondary lymphoid organs $[96,97]$. S1PR1 modulators induce internalization of this receptor and the majority of circulating lymphocytes are sequestered in lymph nodes, decreasing peripheral lymphocyte counts and trafficking of lymphocytes to peripheral tissues (Figure 2) [98,99]. Furthermore, it has been reported that S1P inhibits the growth of epidermal cells, induces differentiation of keratinocytes, and shows antiproliferative and anti-inflammatory effects in mouse models of psoriasis [100-104].

Ponesimod (ACT-128800) is an orally selective S1PR1 agonist, which blocks the egress of T cells from lymphoid organs $[105,106]$. Ponesimod is excreted within 1 week after discontinuation, and this rapid elimination is beneficial in cases including vaccinations and pregnancy $[107,108]$.

In the phase 2 clinical trial, the PASI75 response to ponesimod by week 16 was $46.0 \%$ ( $20 \mathrm{mg}$ ) and $48.1 \%$ (40 mg), as compared to $13.4 \%$ for the placebo. By week 28 , PASI75 was achieved in $71.4 \%$ (20 mg) and 77.4\% (40 mg), respectively [108]. During the trial, dyspnea, increased liver enzyme 
concentrations, headache, nasopharyngitis, bradycardia, pruritus, and dizziness were observed [108]. However, the phase 3 clinical trial of ponesimod in psoriasis has not been started yet, possibly because severe side effects such as lymphopenia, bradycardia, and dyspnea were observed in other S1PR1 modulators [108,109].

\subsection{Rho-Associated Kinase (ROCK2) Inhibitor}

Rho family kinases, consisting of ROCK1 and ROCK2, are serine-threonine kinases activated by Rho GTPases and mediate the phosphorylation of downstream targets in cells [110,111]. KD025 is adenosine triphosphate (ATP) competitive and 100-fold more selective for the ROCK2 isoform when compared with ROCK1, with no significant activity against 300 other intracellular kinases and surface receptors [111,112]. Recent studies showed that oral administration of a selective ROCK2 inhibitor (KD025) in healthy subjects decreases IL17 and IL21 secretion induced by ex vivo stimulation (Figure 2) [111]. Moreover, targeted ROCK2 inhibition shifted the balance between proinflammatory and immunosuppressive T-cell subsets through concurrent regulation of STAT3/STAT5 phosphorylation [113,114].

In the phase 2 clinical trial, KD025 significantly reduced both IL17 and IL23 levels. KD025 also decreased epidermal thickness, K16 expression, and T-cell infiltration in the skin [114]. In addition, the PASI50 response to KD025 (200 mg twice daily) at week 12 was 71\% [114]. In contrast, KD025 significantly increased levels of the immunosuppressive cytokine IL10, but TNF $\alpha$ and IL6 levels were not changed [114]. ROCK2 expression is induced during Th17-skewing conditions and regulates IL17 secretion through a STAT3/IRF4/ROR $\gamma$ t-dependent mechanism in mice and humans $[111,115]$.

\subsection{The AhR Agonist, Tapinarof}

Tapinarof (GSK2894512; 5-[(E)-2-phenylethenyl]-2-(propan-2-yl)benzene-1,3-diol, previously WBI-1001) is a naturally derived polyphenol produced by bacterial symbionts of entomopathogenic nematodes and an AhR agonist [116,117]. In ex vivo human skin, tapinarof reduced Th17 cytokines such as IL17A, IL17F, and IL22 (Figure 2) [117]. In imiquimod-treated mice, tapinarof demonstrated less inflammation, epidermal thickening, and reduced proinflammatory cytokines such as IL17, IL19, IL22, IL23, and IL1 $\beta$ [117]. In addition, tapinarof has an antioxidant activity based on inhibition of reactive oxygen species through the stilbene structure and NRF2 pathway [117].

In the phase 2 clinical trial, the PASI75 response to topical tapinarof at week 12 was $65 \%$ (1\% twice daily) and $56 \%$ ( $1 \%$ once daily) when compared to $16 \%$ (twice daily) and $5 \%$ (once daily) for the placebo. The most frequently reported adverse events were folliculitis and contact dermatitis in the tapinarof groups [118]. Therefore, topical tapinarof is efficacious in the treatment of psoriasis.

\section{Conclusions}

In this review, we summarized new insights regarding the pathogenesis of psoriasis, as it relates to AMPs, DCs, the IL23/IL17 axis, and AhR. Moreover, we summarized new treatments, including JAK inhibitors, ROCK inhibitors, S1P agonists, and AhR agonists. Some of these treatments are currently undergoing clinical trials and are expected to be on the market. To improve the quality of life of psoriatic patients, the choice of available treatments is now increasing.

Funding: This research received no external funding.

Conflicts of Interest: The authors declare no conflict of interest.

\section{References}

1. Griffiths, C.E.; Barker, J.N. Pathogenesis and Clinical Features of Psoriasis. Lancet 2007, 370, 263-271. [CrossRef]

2. Boehncke, W.; Boehncke, S.; Tobin, A.; Kirby, B. The 'psoriatic March': A Concept of how Severe Psoriasis may Drive Cardiovascular Comorbidity. Exp. Dermatol. 2011, 20, 303-307. [CrossRef] [PubMed] 
3. Yamanaka, K.; Mizutani, H. “Inflammatory Skin March": IL-1-mediated Skin Inflammation, Atopic Dermatitis, and Psoriasis to Cardiovascular Events. J. Allergy Clin. Immunol. 2015, 136, 823-824. [CrossRef] [PubMed]

4. Tang, L.; Yang, X.; Liang, Y.; Xie, H.; Dai, Z.; Zheng, G. Transcription Factor Retinoid-Related Orphan Receptor $\gamma \mathrm{t}$ : A Promising Target for the Treatment of Psoriasis. Front. Immunol. 2018, 9, 1210. [CrossRef]

5. Lai, Y.; Gallo, R.L. AMPed up Immunity: How Antimicrobial Peptides have Multiple Roles in Immune Defense. Trends Immunol. 2009, 30, 131-141. [CrossRef]

6. Ogawa, E.; Sato, Y.; Minagawa, A.; Okuyama, R. Pathogenesis of Psoriasis and Development of Treatment. J. Dermatol. 2018, 45, 264-272. [CrossRef]

7. Rendon, A.; Schäkel, K. Psoriasis Pathogenesis and Treatment. Int. J. Mol. Sci. 2019, 20, 1475. [CrossRef]

8. Büchau, A.S.; Gallo, R.L. Innate Immunity and Antimicrobial Defense Systems in Psoriasis. Clin. Dermatol. 2007, 25, 616-624. [CrossRef]

9. Harder, J.; Schröder, J.M. Psoriatic scales: A promising source for the isolation of human skin-derived antimicrobial proteins. J. Leukoc. Biol. 2005, 77, 476-486. [CrossRef]

10. Morizane, S.; Gallo, R.L. Antimicrobial Peptides in the Pathogenesis of Psoriasis. J. Dermatol. 2012, 39, 225-230. [CrossRef]

11. Eckert, R.L.; Broome, A.; Ruse, M.; Robinson, N.; Ryan, D.; Lee, K. S100 Proteins in the Epidermis. J. Investig. Dermatol. 2004, 123, 23-33. [CrossRef] [PubMed]

12. Liang, S.C.; Tan, X.; Luxenberg, D.P.; Karim, R.; Dunussi-Joannopoulos, K.; Collins, M.; Fouser, L.A. Interleukin (IL)-22 and IL-17 are Coexpressed by Th17 Cells and Cooperatively Enhance Expression of Antimicrobial Peptides. J. Exp. Med. 2006, 203, 2271-2279. [CrossRef] [PubMed]

13. Jinquan, T.; Vorum, H.; Larsen, C.G.; Madsen, P.; Rasmussen, H.H.; Gesser, B.; Etzerodt, M.; Honoré, B.; Celis, J.E.; Thestrup-Pedersen, K. Psoriasin: A Novel Chemotactic Protein. J. Investig. Dermatol. 1996, 107, 5-10. [CrossRef] [PubMed]

14. Frohm, M.; Agerberth, B.; Ahangari, G.; Backdahl, M.S.; Liden, S.; Wigzell, H.; Gudmundsson, G.H. The Expression of the Gene Coding for the Antibacterial Peptide LL-37 is Induced in Human Keratinocytes during Inflammatory Disorders. J. Biol. Chem. 1997, 272, 15258-15263. [CrossRef]

15. Lande, R.; Gregorio, J.; Facchinetti, V.; Chatterjee, B.; Wang, Y.H.; Homey, B.; Cao, W.; Wang, Y.H.; Su, B.; Nestle, F.O.; et al. Plasmacytoid Dendritic Cells Sense Self-DNA Coupled with Antimicrobial Peptide. Nature 2007, 449, 564-569. [CrossRef] [PubMed]

16. Morizane, S.; Yamasaki, K.; Mühleisen, B.; Kotol, P.F.; Murakami, M.; Aoyama, Y.; Iwatsuki, K.; Hata, T.; Gallo, R.L. Cathelicidin Antimicrobial Peptide LL-37 in Psoriasis Enables Keratinocyte Reactivity Against TLR9 Ligands. J. Investig. Dermatol. 2012, 132, 135-143. [CrossRef]

17. Hänsel, A.; Günther, C.; Ingwersen, J.; Starke, J.; Schmitz, M.; Bachmann, M.; Meurer, M.; Rieber, E.P.; Schäkel, K. Human Slan (6-Sulfo LacNAc) Dendritic Cells are Inflammatory Dermal Dendritic Cells in Psoriasis and Drive Strong Th17/Th1 T-Cell Responses. J. Allergy Clin. Immunol. 2011, 127, 787-794. [CrossRef]

18. Mabuchi, T.; Hirayama, N. Binding Affinity and Interaction of LL-37 with HLA-C06:02 in Psoriasis. J. Investig. Dermatol. 2016, 136, 1901-1903. [CrossRef]

19. Arakawa, A.; Siewert, K.; Stöhr, J.; Besgen, P.; Kim, S.; Rühl, G.; Nickel, J.; Vollmer, S.; Thomas, P.; Krebs, S.; et al. Melanocyte Antigen Triggers Autoimmunity in Human Psoriasis. J. Exp. Med. 2015, 212, $2203-2212$. [CrossRef]

20. Krueger, J.G. An autoimmune "attack" on melanocytes triggers psoriasis and cellular hyperplasia. J. Exp. Med. 2015, 212, 2186. [CrossRef]

21. Nishimoto, S.; Kotani, H.; Tsuruta, S.; Shimizu, N.; Ito, M.; Shichita, T.; Morita, R.; Takahashi, H.; Amagai, M.; Yoshimura, A. Th17 Cells Carrying TCR Recognizing Epidermal Autoantigen Induce Psoriasis-Like Skin Inflammation. J. Immunol. 2013, 191, 3065-3072. [CrossRef] [PubMed]

22. Chiricozzi, A.; Romanelli, P.; Volpe, E.; Borsellino, G.; Romanelli, M. Scanning the Immunopathogenesis of Psoriasis. Int. J. Mol. Sci. 2018, 19, 179. [CrossRef] [PubMed]

23. Fuentes-Duculan, J.; Bonifacio, K.M.; Kunjravia, N.; Hawkes, J.E.; Cueto, I.; Li, X.; Garcet, S.; Krueger, J.G. Autoantigens ADAMTSL5 and LL-37 are significantly Upregulated in Active Psoriasis and Associated with Dendritic Cells and Macrophages. Exp. Dermatol. 2017, 26, 1075-1082. [CrossRef] [PubMed] 
24. Bonifacio, K.M.; Kunjravia, N.; Krueger, J.G.; Fuentes-Duculan, J. Cutaneous Expression of a Disintegrin-Like and Metalloprotease Domain Containing Thrombospondin Type 1 Motif-Like 5 (ADAMTSL5) in Psoriasis Goes Beyond Melanocytes. J. Pigment Disord. 2016, 3, 3. [CrossRef]

25. Wang, A.; Bai, Y. Dendritic Cells: The Driver of Psoriasis. J. Dermatol. 2020, 47, 104-113. [CrossRef]

26. Macri, C.; Pang, E.S.; Patton, T.; O'Keeffe, M. Dendritic cell subsets. Semin. Cell. Dev. Biol. 2018, 84, 11-21. [CrossRef]

27. Collin, M.; McGovern, N.; Haniffa, M. Human Dendritic Cell Subsets. Immunology 2013, 140, 22-30. [CrossRef]

28. Panda, S.K.; Kolbeck, R.; Sanjuan, M.A. Plasmacytoid Dendritic Cells in Autoimmunity. Curr. Opin. Immunol. 2016, 44, 20-25. [CrossRef]

29. Takagi, H.; Arimura, K.; Uto, T.; Fukaya, T.; Nakamura, T.; Choijookhuu, N.; Hishikawa, Y.; Sato, K. Plasmacytoid Dendritic Cells Orchestrate TLR7-Mediated Innate and Adaptive Immunity for the Initiation of Autoimmune Inflammation. Sci. Rep. 2016, 6, 24477. [CrossRef]

30. Kopfnagel, V.; Wagenknecht, S.; Harder, J.; Hofmann, K.; Kleine, M.; Buch, A.; Sodeik, B.; Werfel, T. RNase 7 Strongly Promotes TLR9-Mediated DNA Sensing by Human Plasmacytoid Dendritic Cells. J. Investig. Dermatol. 2018, 138, 872-881. [CrossRef]

31. Lande, R.; Chamilos, G.; Ganguly, D.; Demaria, O.; Frasca, L.; Durr, S.; Conrad, C.; Schröder, J.; Gilliet, M. Cationic Antimicrobial Peptides in Psoriatic Skin Cooperate to Break Innate Tolerance to self-DNA. Eur. J. Immunol. 2015, 45, 203-213. [CrossRef] [PubMed]

32. Nestle, F.O.; Conrad, C.; Tun-Kyi, A.; Homey, B.; Gombert, M.; Boyman, O.; Burg, G.; Liu, Y.; Gilliet, M. Plasmacytoid Predendritic Cells Initiate Psoriasis through Interferon-A Production. J. Exp. Med. 2005, 202, 135-143. [CrossRef] [PubMed]

33. Lande, R.; Gilliet, M. Plasmacytoid Dendritic Cells: Key Players in the Initiation and Regulation of Immune Responses. Annu. N. Y. Acad. Sci. 2010, 1183, 89-103. [CrossRef] [PubMed]

34. Santini, S.M.; Lapenta, C.; Logozzi, M.; Parlato, S.; Spada, M.; Di Pucchio, T.; Belardelli, F. Type I Interferon as a Powerful Adjuvant for Monocyte-Derived Dendritic Cell Development and Activity in Vitro and in Hu-PBL-SCID Mice. J. Exp. Med. 2000, 191, 1777-1788. [CrossRef]

35. Ueyama, A.; Yamamoto, M.; Tsujii, K.; Furue, Y.; Imura, C.; Shichijo, M.; Yasui, K. Mechanism of Pathogenesis of Imiquimod-induced Skin Inflammation in the Mouse: A Role for Interferon-alpha in Dendritic Cell Activation by Imiquimod. J. Dermatol. 2014, 41, 135-143. [CrossRef]

36. Tohyama, M.; Yang, L.; Hanakawa, Y.; Dai, X.; Shirakata, Y.; Sayama, K. IFN-A Enhances IL-22 Receptor Expression in Keratinocytes: A Possible Role in the Development of Psoriasis. J. Investig. Dermatol. 2012, 132, 1933-1935. [CrossRef]

37. Liu, J.; Cao, X. Regulatory Dendritic Cells in Autoimmunity: A Comprehensive Review. J. Autoimmun. 2015, 63, 1-12. [CrossRef]

38. Manicassamy, S.; Pulendran, B. Dendritic Cell Control of Tolerogenic Responses. Immunol. Rev. 2011, 241, 206-227. [CrossRef]

39. Buhl, T.; Saleh, M.M.; Schön, M.P. More Tolerance for Dendritic Cells in Psoriasis. Exp. Dermatol. 2017, 26, 335-337. [CrossRef]

40. Ganguly, D.; Haak, S.; Sisirak, V.; Reizis, B. The Role of Dendritic Cells in Autoimmunity. Nat. Rev. Immunol. 2013, 13, 566-577. [CrossRef]

41. Auriemma, M.; Brzoska, T.; Klenner, L.; Kupas, V.; Goerge, T.; Voskort, M.; Zhao, Z.; Sparwasser, T.; Luger, T.A.; Loser, K. A-MSH-Stimulated Tolerogenic Dendritic Cells Induce Functional Regulatory T Cells and Ameliorate Ongoing Skin Inflammation. J. Investig. Dermatol. 2012, 132, 1814-1824. [CrossRef] [PubMed]

42. Terhorst, D.; Chelbi, R.; Wohn, C.; Malosse, C.; Tamoutounour, S.; Jorquera, A.; Bajenoff, M.; Dalod, M.; Malissen, B.; Henri, S. Dynamics and Transcriptomics of Skin Dendritic Cells and Macrophages in an Imiquimod-Induced, Biphasic Mouse Model of Psoriasis. J. Immunol. 2015, 195, 4953-4961. [CrossRef] [PubMed]

43. Bos, J.D.; Hulsebosch, H.J.; Krieg, S.R.; Bakker, P.M.; Cormane, R.H. Immunocompetent Cells in Psoriasis. in Situ Immunophenotyping by Monoclonal Antibodies. Arch. Dermatolog. Res. 1983, 275, 181-189. [CrossRef] [PubMed]

44. Martini, E.; Wikén, M.; Cheuk, S.; Sérézal, I.G.; Baharom, F.; Ståhle, M.; Smed-Sörensen, A.; Eidsmo, L. Dynamic Changes in Resident and Infiltrating Epidermal Dendritic Cells in Active and Resolved Psoriasis. J. Investig. Dermatol. 2017, 137, 865-873. [CrossRef] 
45. Eaton, L.H.; Mellody, K.T.; Pilkington, S.M.; Dearman, R.J.; Kimber, I.; Griffiths, C.E.M. Impaired Langerhans Cell Migration in Psoriasis is due to an Altered Keratinocyte Phenotype Induced by interleukin-17. Br. J. Dermatol. 2018, 178, 1364-1372. [CrossRef]

46. Singh, T.P.; Zhang, H.H.; Borek, I.; Wolf, P.; Hedrick, M.N.; Singh, S.P.; Kelsall, B.L.; Clausen, B.E.; Farber, J.M. Monocyte-Derived Inflammatory Langerhans Cells and Dermal Dendritic Cells Mediate Psoriasis-Like Inflammation. Nat. Commun. 2016, 7, 13581. [CrossRef]

47. Korn, T.; Bettelli, E.; Oukka, M.; Kuchroo, V.K. IL-17 and Th17 Cells. Annu. Rev. Immunol. 2009, $27,485-517$. [CrossRef]

48. Res, P.C.M.; Piskin, G.; de Boer, O.J.; van der Loos, C.M.; Teeling, P.; Bos, J.D.; Teunissen, M.B.M. Overrepresentation of IL-17A and IL-22 Producing CD8 T Cells in Lesional Skin Suggests their Involvement in the Pathogenesis of Psoriasis. PLoS ONE 2010, 5, e14108. [CrossRef]

49. Kim, J.; Krueger, J.G. Highly Effective New Treatments for Psoriasis Target the IL-23 Type 17 T Cell Autoimmune Axis. Annu. Rev. Med. 2017, 68, 255-269. [CrossRef]

50. Hawkes, J.E.; Chan, T.C.; Krueger, J.G. Psoriasis Pathogenesis and the Development of Novel Targeted Immune Therapies. J. Allergy Clin. Immunol. 2017, 140, 645-653. [CrossRef]

51. Chiricozzi, A.; Guttman-Yassky, E.; Suárez-Fariñas, M.; Nograles, K.E.; Tian, S.; Cardinale, I.; Chimenti, S.; Krueger, J.G. Integrative Responses to IL-17 and TNF-A in Human Keratinocytes Account for Key Inflammatory Pathogenic Circuits in Psoriasis. J. Investig. Dermatol. 2011, 131, 677-687. [CrossRef] [PubMed]

52. Ghoreschi, K.; Laurence, A.; Yang, X.; Tato, C.M.; McGeachy, M.J.; Konkel, J.E.; Ramos, H.L.; Wei, L.; Davidson, T.S.; Bouladoux, N.; et al. Generation of Pathogenic TH17 Cells in the Absence of TGF-B Signalling. Nature 2010, 467, 967-971. [CrossRef] [PubMed]

53. Eyerich, S.; Eyerich, K.; Pennino, D.; Carbone, T.; Nasorri, F.; Pallotta, S.; Cianfarani, F.; Odorisio, T.; Traidl-Hoffmann, C.; Behrendt, H.; et al. Th22 Cells Represent a Distinct Human T Cell Subset Involved in Epidermal Immunity and Remodeling. J. Clin. Investig. 2009, 119, 3573-3585. [CrossRef] [PubMed]

54. Cho, K.; Suh, J.W.; Lee, K.H.; Kang, J.L.; Woo, S. IL-17 and IL-22 Enhance Skin Inflammation by Stimulating the Secretion of IL-1 $\beta$ by Keratinocytes Via the ROS-NLRP3-Caspase-1 Pathway. Int. Immunol. 2012, 24, 147-158. [CrossRef] [PubMed]

55. Harper, E.G.; Guo, C.; Rizzo, H.; Lillis, J.V.; Kurtz, S.E.; Skorcheva, I.; Purdy, D.; Fitch, E.; Iordanov, M.; Blauvelt, A. Th17 Cytokines Stimulate CCL20 Expression in Keratinocytes in Vitro and in Vivo: Implications for Psoriasis Pathogenesis. J. Investig. Dermatol. 2009, 129, 2175-2183. [CrossRef]

56. Heidenreich, R.; Röcken, M.; Ghoreschi, K. Angiogenesis Drives Psoriasis Pathogenesis. Int. J. Exp. Pathol. 2009, 90, 232-248. [CrossRef] [PubMed]

57. Denison, M.S.; Nagy, S.R. Activation of the Aryl Hydrocarbon Receptor by Structurally Diverse Exogenous and Endogenous Chemicals. Annu. Rev. Pharma. Toxicol. 2003, 43, 309. [CrossRef]

58. Stockinger, B.; Meglio, P.D.; Gialitakis, M.; Duarte, J.H. The Aryl Hydrocarbon Receptor: Multitasking in the Immune System. Annu. Rev. Immunol. 2014, 32, 403-432. [CrossRef]

59. Furue, M.; Hashimoto-Hachiya, A.; Tsuji, G. Aryl Hydrocarbon Receptor in Atopic Dermatitis and Psoriasis. Int. J. Mol. Sci. 2019, 20, 5424. [CrossRef]

60. Ramirez, J.; Brembilla, N.C.; Sorg, O.; Chicheportiche, R.; Matthes, T.; Dayer, J.; Saurat, J.; Roosnek, E.; Chizzolini, C. Activation of the Aryl Hydrocarbon Receptor Reveals Distinct Requirements for IL-22 and IL-17 Production by Human T Helper Cells. Eur. J. Immunol. 2010, 40, 2450-2459. [CrossRef]

61. Zhu, Z.; Chen, J.; Lin, Y.; Zhang, C.; Li, W.; Qiao, H.; Fu, M.; Dang, E.; Wang, G. Aryl Hydrocarbon Receptor in Cutaneous Vascular Endothelial Cells Restricts Psoriasis Development by Negatively Regulating Neutrophil Recruitment. J. Investig. Dermatol. 2020, 140, 1233-1243. [CrossRef] [PubMed]

62. Chularojanamontri, L.; Silpa-archa, N.; Wongpraparut, C.; Limphoka, P. Long-term Safety and Drug Survival of Acitretin in Psoriasis: A Retrospective Observational Study. Int. J. Dermatol. 2019, 58, 593-599. [CrossRef] [PubMed]

63. Dogra, S.; Jain, A.; Kanwar, A.J. Efficacy and Safety of Acitretin in Three Fixed Doses of 25, 35 and $50 \mathrm{mg}$ in Adult Patients with Severe Plaque Type Psoriasis: A Randomized, Double Blind, Parallel Group, Dose Ranging Study. J. Eur. Acad. Dermatol. 2013, 27, e305-e311. [CrossRef] [PubMed] 
64. Raaby, L.; Zachariae, C.; Østensen, M.; Heickendorff, L.; Thielsen, P.; Grønbæk, H.; Skov, L.; Kyvsgaard, N.; Madsen, J.; Heidenheim, M.; et al. Methotrexate Use and Monitoring in Patients with Psoriasis: A Consensus Report Based on a Danish Expert Meeting. Acta Derm. Venereol. 2017, 97, 426-432. [CrossRef]

65. West, J.; Ogston, S.; Foerster, J. Safety and Efficacy of Methotrexate in Psoriasis: A Meta-Analysis of Published Trials. PLoS ONE 2016, 11, e0153740. [CrossRef]

66. Maza, A.; Montaudié, H.; Sbidian, E.; Gallini, A.; Aractingi, S.; Aubin, F.; Bachelez, H.; Cribier, B.; Joly, P.; Jullien, D.; et al. Oral Cyclosporin in Psoriasis: A Systematic Review on Treatment Modalities, Risk of Kidney Toxicity and Evidence for use in Non-plaque Psoriasis. J. Eur. Acad. Dermatol. Venereol. 2011, 25, 19-27. [CrossRef]

67. Papp, K.; Reich, K.; Leonardi, C.L.; Kircik, L.; Chimenti, S.; Langley, R.G.; Hu, C.; Stevens, R.M.; Day, R.M.; Gordon, K.B.; et al. Apremilast, an oral phosphodiesterase 4 (PDE4) inhibitor, in patients with moderate to severe plaque psoriasis: Results of a phase III, randomized, controlled trial (Efficacy and Safety Trial Evaluating the Effects of Apremilast in Psoriasis [ESTEEM] 1). J. Am. Acad. Dermatol. 2015, 73, 37-49. [CrossRef]

68. Mariette, X.; Förger, F.; Abraham, B.; Flynn, A.D.; Moltó, A.; Flipo, R.; van Tubergen, A.; Shaughnessy, L.; Simpson, J.; Teil, M.; et al. Lack of Placental Transfer of Certolizumab Pegol during Pregnancy: Results from CRIB, a Prospective, Postmarketing, Pharmacokinetic Study. Ann. Rheum. Dis. 2018, 77, 228-233. [CrossRef]

69. Gall, J.S.; Kalb, R.E. Infliximab for the Treatment of Plaque Psoriasis. Biologics 2008, 2, 115-124.

70. Alwawi, E.A.; Mehlis, S.L.; Gordon, K.B. Treating Psoriasis with Adalimumab. Ther. Clin. Risk Manag. 2008, $4,345-351$.

71. Blauvelt, A.; Reich, K.; Lebwohl, M.; Burge, D.; Arendt, C.; Peterson, L.; Drew, J.; Rolleri, R.; Gottlieb, A.B. Certolizumab Pegol for the Treatment of Patients with Moderate-to-severe Chronic Plaque Psoriasis: Pooled Analysis of Week 16 Data from Three Randomized Controlled Trials. J. Eur. Acad. Dermatol. Venereol. 2018, 33, 546-552. [CrossRef] [PubMed]

72. Farhi, D. Ustekinumab for the treatment of psoriasis: Review of three multicenter clinical trials. Drugs Today 2010, 46, 259-264. [CrossRef] [PubMed]

73. Nogueira, M.; Torres, T. Guselkumab for the treatment of psoriasis—evidence to date. Drugs Context 2019, 8, 1-11. [CrossRef] [PubMed]

74. Witjes, H.; Khatri, A.; Diderichsen, P.M.; Mandema, J.; Othman, A.A. Meta-Analyses of Clinical Efficacy of Risankizumab and Adalimumab in Chronic Plaque Psoriasis: Supporting Evidence of Risankizumab Superiority. Clin. Pharmacol. Ther. 2019, 107, 435-442. [CrossRef] [PubMed]

75. Blauvelt, A.; Sofen, H.; Papp, K.; Gooderham, M.; Tyring, S.; Zhao, Y.; Lowry, S.; Mendelsohn, A.; Parno, J.; Reich, K. Tildrakizumab efficacy and impact on quality of life up to 52 weeks in patients with moderate-to-severe psoriasis: A pooled analysis of two randomized controlled trials. J. Eur. Acad. Dermatol. Venereol. 2019, 33, 2305-2312. [CrossRef]

76. López-Ferrer, A.; Vilarrasa, E.; Puig, L. Secukinumab (AIN457) for the treatment of psoriasis. Expert Rev. Clin. Immunol. 2015, 11, 1177-1188. [CrossRef] [PubMed]

77. Papp, K.A.; Leonardi, C.L.; Blauvelt, A.; Reich, K.; Korman, N.J.; Ohtsuki, M.; Paul, C.; Ball, S.; Cameron, G.S.; Erickson, J.; et al. Ixekizumab Treatment for Psoriasis: Integrated Efficacy Analysis of Three Double-Blinded, Controlled Studies (UNCOVER-1, UNCOVER-2, UNCOVER-3). Br. J. Dermatol. 2018, 178, 674-681. [CrossRef]

78. Foulkes, A.C.; Warren, R.B. Brodalumab in Psoriasis: Evidence to Date and Clinical Potential. Drugs Context 2019, 8, 1-11. [CrossRef]

79. Pandya, V.B.; Kumar, S.; Sachchidanand; Sharma, R.; Desai, R.C. Combating Autoimmune Diseases with Retinoic Acid Receptor-Related Orphan Receptor- $\gamma$ (ROR $\gamma$ or RORc) Inhibitors: Hits and Misses. J. Med. Chem. 2018, 61, 10976-10995. [CrossRef]

80. Kang, E.G.; Wu, S.; Gupta, A.; von Mackensen, Y.L.; Siemetzki, H.; Freudenberg, J.; Wigger-Alberti, W.; Yamaguchi, Y. A phase I randomized controlled trial to evaluate safety and clinical effect of topically applied GSK2981278 ointment in a psoriasis plaque test. Br. J. Dermatol. 2018, 178, 1427-1429. [CrossRef] 
81. Imura, C.; Ueyama, A.; Sasaki, Y.; Shimizu, M.; Furue, Y.; Tai, N.; Tsujii, K.; Katayama, K.; Okuno, T.; Shichijo, M.; et al. A Novel ROR $\gamma \mathrm{t}$ Inhibitor is a Potential Therapeutic Agent for the Topical Treatment of Psoriasis with Low Risk of Thymic Aberrations. J. Dermatol. Sci. 2019, 93, 176-185. [CrossRef] [PubMed]

82. Ganesan, R.; Raymond, E.L.; Mennerich, D.; Woska, J.R.; Caviness, G.; Grimaldi, C.; Ahlberg, J.; Perez, R.; Roberts, S.; Yang, D.; et al. Generation and Functional Characterization of Anti-Human and Anti-Mouse IL-36R Antagonist Monoclonal Antibodies. $m A$ ss 2017, 9, 1143-1154. [CrossRef] [PubMed]

83. Bachelez, H.; Choon, S.; Marrakchi, S.; Burden, A.D.; Tsai, T.; Morita, A.; Turki, H.; Hall, D.B.; Shear, M.; Baum, P.; et al. Inhibition of the Interleukin-36 Pathway for the Treatment of Generalized Pustular Psoriasis. N. Engl. J. Med. 2019, 380, 981-983. [CrossRef] [PubMed]

84. O'Shea, J.J.; Schwartz, D.M.; Villarino, A.V.; Gadina, M.; McInnes, I.B.; Laurence, A. The JAK-STAT Pathway: Impact on Human Disease and Therapeutic Intervention. Annu. Rev. Med. 2015, 66, 311-328. [CrossRef]

85. Schwartz, D.M.; Kanno, Y.; Villarino, A.; Ward, M.; Gadina, M.; O'Shea, J.J. JAK Inhibition as a Therapeutic Strategy for Immune and Inflammatory Diseases. Nat. Rev. Drug Discov. 2017, 16, 843-862. [CrossRef]

86. Papp, K.A.; Menter, M.A.; Abe, M.; Elewski, B.; Feldman, S.R.; Gottlieb, A.B.; Langley, R.; Luger, T.; Thaci, D.; Buonanno, M.; et al. Tofacitinib, an Oral Janus Kinase Inhibitor, for the Treatment of Chronic Plaque Psoriasis: Results from Two Randomized, Placebo-controlled, Phase III Trials. Br. J. Dermatol. 2015, 173, 949-961. [CrossRef]

87. Bissonnette, R.; Iversen, L.; Sofen, H.; Griffiths, C.E.M.; Foley, P.; Romiti, R.; Bachinsky, M.; Rottinghaus, S.T.; Tan, H.; Proulx, J.; et al. Tofacitinib Withdrawal and Retreatment in Moderate-to-severe Chronic Plaque Psoriasis: A Randomized Controlled Trial. Br. J. Dermatol. 2015, 172, 1395-1406. [CrossRef]

88. Bachelez, H.; Kerkhof, P.C.M.; Strohal, R.; Kubanov, A.; Valenzuela, F.; Lee, J.; Yakusevich, V.; Chimenti, S.; Papacharalambous, J.; Proulx, J.; et al. Tofacitinib Versus Etanercept or Placebo in Moderate-to-Severe Chronic Plaque Psoriasis: A Phase 3 Randomised Non-Inferiority Trial. Lancet 2015, 386, 552-561. [CrossRef]

89. Zhang, J.; Tsai, T.; Lee, M.; Zheng, M.; Wang, G.; Jin, H.; Gu, J.; Li, R.; Liu, Q.; Chen, J.; et al. The Efficacy and Safety of Tofacitinib in Asian Patients with Moderate to Severe Chronic Plaque Psoriasis: A Phase 3, Randomized, Double-Blind, Placebo-Controlled Study. J. Dermatol. Sci. 2017, 88, 36-45. [CrossRef]

90. Papp, K.A.; Menter, A.; Strober, B.; Langley, R.G.; Buonanno, M.; Wolk, R.; Gupta, P.; Krishnaswami, S.; Tan, H.; Harness, J.A. Efficacy and Safety of Tofacitinib, an Oral Janus Kinase Inhibitor, in the Treatment of Psoriasis: A Phase 2b Randomized Placebo-controlled Dose-ranging Study. Br. J. Dermatol. 2012, 167, 668-677. [CrossRef]

91. Banerjee, S.; Biehl, A.; Gadina, M.; Hasni, S.; Schwartz, D.M. JAK-STAT Signaling as a Target for Inflammatory and Autoimmune Diseases: Current and Future Prospects. Drugs 2017, 77, 521-546. [CrossRef] [PubMed]

92. Page, K.M.; Suarez-Farinas, M.; Suprun, M.; Zhang, W.; Garcet, S.; Fuentes-Duculan, J.; Li, X.; Scaramozza, M.; Kieras, E.; Banfield, C.; et al. Molecular and Cellular Responses to the TYK2/JAK1 Inhibitor PF-06700841 Reveal Reduction of Skin Inflammation in Plaque Psoriasis. J. Investig. Dermatol. 2020, 140, 1546-1555. [CrossRef] [PubMed]

93. Solimani, F.; Meier, K.; Ghoreschi, K. Emerging Topical and Systemic JAK Inhibitors in Dermatology. Front. Immunol. 2019, 10, 2847. [CrossRef] [PubMed]

94. Borodzicz, S.; Rudnicka, L.; Mirowska-Guzel, D.; Cudnoch-Jedrzejewska, A. The Role of Epidermal Sphingolipids in Dermatologic Diseases. Lipids Health Dis. 2016, 15, 13. [CrossRef] [PubMed]

95. Kunkel, G.T.; Maceyka, M.; Milstien, S.; Spiegel, S. Targeting the Sphingosine-1-Phosphate Axis in Cancer, Inflammation and Beyond. Nat. Rev. Drug Discov. 2013, 12, 688-702. [CrossRef]

96. Krause, A.; D'Ambrosio, D.; Dingemanse, J. Modeling Clinical Efficacy of the S1P Receptor Modulator Ponesimod in Psoriasis. J. Dermatol. Sci. 2018, 89, 136-145. [CrossRef]

97. JCyster, J.G.; Schwab, S.R. Sphingosine-1-Phosphate and Lymphocyte Egress from Lymphoid Organs. Annu. Rev. Immunol. 2012, 30, 69-94. [CrossRef]

98. Chew, W.S.; Wang, W.; Herr, D.R. To fingolimod and beyond: The rich pipeline of drug candidates that target S1P signaling. Pharmacol. Res. 2016, 113, 521-532. [CrossRef]

99. Piali, L.; Froidevaux, S.; Hess, P.; Nayler, O.; Bolli, M.H.; Schlosser, E.; Kohl, C.; Steiner, B.; Clozel, M. The Selective Sphingosine 1-Phosphate Receptor 1 Agonist Ponesimod Protects against Lymphocyte-Mediated Tissue Inflammation. J. Pharmacol. Exp. Ther. 2011, 337, 547-556. [CrossRef] 
100. Ji, M.; Xue, N.; Lai, F.; Zhang, X.; Zhang, S.; Wang, Y.; Jin, J.; Chen, X. Validating a Selective S1P1 Receptor Modulator Syl930 for Psoriasis Treatment. Biol. Pharm. Bull. 2018, 41, 592-596. [CrossRef]

101. Manggau, M.; Kim, D.; Ruwisch, L.; Vogler, R.; Schäfer-Korting, M.; Kleuser, B. boothe Formation of Sphingosine-1-Phosphate. J. Investig. Dermatol. 2001, 117, 1241-1249. [CrossRef] [PubMed]

102. Vogler, R.; Sauer, B.; Kim, D.S.; Schäfer-Korting, M.; Kleuser, B.; Sch, M. Sphingosine-1-Phosphate and Its Potentially Paradoxical Effects on Critical Parameters of Cutaneous Wound Healing. J. Investig. Dermatol. 2003, 120, 693-700. [CrossRef] [PubMed]

103. Schüppel, M.; Kürschner, U.; Kleuser, U.; Schäfer-Korting, M.; Kleuser, B. Sphingosine 1-Phosphate Restrains Insulin-Mediated Keratinocyte Proliferation via Inhibition of Akt through the S1P2 Receptor Subtype. J. Investig. Dermatol. 2008, 128, 1747-1756. [CrossRef] [PubMed]

104. Schaper, K.; Dickhaut, J.; Japtok, L.; Kietzmann, M.; Mischke, R.; Kleuser, B.; Bäumer, W. Sphingosine-1-Phosphate Exhibits Anti-Proliferative and Anti-Inflammatory Effects in Mouse Models of Psoriasis. J. Dermatol. Sci. 2013, 71, 29-36. [CrossRef] [PubMed]

105. Park, S.; Im, D. Sphingosine 1-Phosphate Receptor Modulators and Drug Discovery. Biomol. Ther. 2017, 25, 80-90. [CrossRef]

106. Bolli, M.H.; Abele, S.; Binkert, C.; Bravo, R.; Buchmann, S.; Bur, D.; Gatfield, J.; Hess, P.; Kohl, C.; Mangold, C.; et al. 2-Imino-Thiazolidin-4-One Derivatives as Potent, Orally Active S1P1 Receptor Agonists. J. Med. Chem. 2010, 53, 4198-4211. [CrossRef]

107. D'Ambrosio, D.; Freedman, M.S.; Prinz, J. Ponesimod, a Selective S1P1 Receptor Modulator: A Potential Treatment for Multiple Sclerosis and Other Immune-Mediated Diseases. Ther. Adv. Chronic Dis. 2016, 7, 18-33. [CrossRef]

108. Vaclavkova, A.; Chimenti, S.; Arenberger, P.; Hóllo, P.; Sator, P.G.; Burcklen, M.; Stefani, M.; D’Ambrosio, D. Oral ponesimod in patients with chronic plaque psoriasis: A randomised, double-blind, placebo-controlled phase 2 trial. Lancet 2014, 384, 2036-2045. [CrossRef]

109. Bell, M.; Foley, D.; Naylor, C.; Robinson, C.; Riley, J.; Epemolu, O.; Scullion, P.; Shishikura, Y.; Katz, E.; Mclean, W.H.I.; et al. Discovery of Super Soft-Drug Modulators of Sphingosine-1-Phosphate Receptor 1. Bioorg. Med. Chem. 2018, 28, 3255-3259. [CrossRef]

110. Riento, K.; Ridley, A.J. ROCKs. multifunctional kinases in cell behavior. Nat. Rev. Mol. Cell Biol. 2003, 4, 446-456. [CrossRef]

111. Zanin-Zhorov, A.; Weiss, J.M.; Nyuydzefe, M.S.; Chen, W.; Scher, J.U.; Mo, R.; Depoil, D.; Rao, N.; Liu, B.; Wei, J.; et al. Selective Oral ROCK2 Inhibitor Down-Regulates IL-21 and IL-17 Secretion in Human T Cells Via STAT3-Dependent Mechanism. Proc. Natl. Acad. Sci. USA 2014, 111, 16814-16819. [CrossRef] [PubMed]

112. Lee, J.H.; Zheng, Y.; von Bornstadt, D.; Wei, Y.; Balcioglu, A.; Daneshmand, A.; Yalcin, N.; Yu, E.; Herisson, F.; Atalay, Y.B.; et al. Selective ROCK2 Inhibition in Focal Cerebral Ischemia. Ann. Clin. Transl. Neurol. 2014, 1, 2-14. [PubMed]

113. Flynn, R.; Paz, K.; Du, J.; Reichenbach, D.K.; Taylor, P.A.; Panoskaltsis-Mortari, A.; Vulic, A.; Luznik, L.; MacDonald, K.K.P.; Hill, G.R.; et al. Targeted Rho-Associated Kinase 2 Inhibition Suppresses Murine and Human Chronic GVHD through a Stat3-Dependent Mechanism. Blood 2016, 127, 2144-2154. [CrossRef] [PubMed]

114. Zanin-Zhorov, A.; Weiss, J.M.; Trzeciak, A.; Chen, W.; Zhang, J.; Nyuydzefe, M.S.; Arencibia, C.; Polimera, S.; Schueller, O.; Fuentes-Duculan, J.; et al. Cutting Edge: Selective Oral ROCK2 Inhibitor Reduces Clinical Scores in Patients with Psoriasis Vulgaris and Normalizes Skin Pathology via Concurrent Regulation of IL-17 and IL-10. J. Immunol. 2017, 198, 3809-3814. [CrossRef]

115. Biswas, P.S.; Gupta, S.; Chang, E.; Song, L.; Stirzaker, R.A.; Liao, J.K.; Bhagat, G.; Pernis, A.B. Phosphorylation of IRF4 by ROCK2 Regulates IL-17 and IL-21 Production and the Development of Autoimmunity in Mice. J. Clin. Investig. 2010, 120, 3280-3295. [CrossRef]

116. Richardson, W.H.; Schmidt, T.M.; Nealson, K.H. Identification of an anthraquinone pigment and a hydroxystilbene antibiotic from Xenorhabdus luminescens. Appl. Environ. Microbiol. 1988, 54, 1602-1605. [CrossRef] 
117. Smith, S.H.; Jayawickreme, C.; Rickard, D.J.; Nicodeme, E.; Bui, T.; Simmons, C.; Coquery, C.M.; Neil, J.; Pryor, W.M.; Mayhew, D.; et al. Tapinarof is a Natural AhR Agonist that Resolves Skin Inflammation in Mice and Humans. J. Investig. Dermatol. 2017, 137, 2110-2119. [CrossRef]

118. Robbins, K.; Bissonnette, R.; Maeda-Chubachi, T.; Ye, L.; Peppers, J.; Gallagher, K.; Kraus, J.E. Phase 2, Randomized Dose-Finding Study of Tapinarof (GSK2894512 Cream) for the Treatment of Plaque Psoriasis. J. Am. Acad. Dermatol. 2019, 80, 714-721. [CrossRef]

(C) 2020 by the authors. Licensee MDPI, Basel, Switzerland. This article is an open access article distributed under the terms and conditions of the Creative Commons Attribution (CC BY) license (http://creativecommons.org/licenses/by/4.0/). 